\title{
PROVENANCE OF MIDDLE STONE AGE OBSIDIAN ARTEFACTS FROM THE CENTRAL SECTOR OF THE MAIN ETHIOPIAN RIFT VALLEY
}

\author{
Agazi Negash ${ }^{1}$, F. H. Brown ${ }^{2}$, Mulugeta Alene ${ }^{3}$ and B. Nash ${ }^{2}$ \\ ${ }^{1}$ Department of Archaeology and Heritage Management, College of Social Sciences and Humanities, \\ and Paleoanthropology and Paleoenvironment Program Unit, College of Natural Sciences, \\ Addis Ababa University, PO Box 1176, Addis Ababa, Ethiopia \\ E-mail: agazi_negash@yahoo.com \\ ${ }^{2}$ Department of Geology and Geophysics, University of Utah, Salt Lake City, Utah 84112, USA \\ ${ }^{3}$ Department of Earth Sciences, College of Natural Sciences, Addis Ababa University, \\ PO Box 1176, Addis Ababa, Ethiopia
}

\begin{abstract}
The Gademotta/Kulkuletti sites, located in the central part of the Main Ethiopian Rift Valley, represent the earliest Middle Stone Age (MSA) sequences in the country. Here we present the geochemical provenance of obsidian archaeological artefact recovered through excavation at the site. The artefacts and source materials were characterized by EDXRF and electron microprobe. Results show that the artefacts were procured from two sources, one local, and one presumably more distant, implying that despite the local availability of good quality raw material, not all obsidians were procured from a nearby source.
\end{abstract}

Key words/phrases: Gademotta, Kulkuletti, Middle Stone Age, obsidian, provenance

\section{INTRODUCTION}

The Middle Stone Age (MSA), a period extending from about 300 to $50 \mathrm{ka}$ ago, is critical to understanding the emergence of anatomically modern humans. Regardless of one's propensity to any of the hypotheses constructed about the origins of anatomically modern humans, there is general agreement among investigators that long distance contact or interaction and/or transport of lithic raw materials is one of the key aspects of the emergence of modern behaviour [see McBrearty and Brooks (2000) for a review].

One way of investigating such aspects of behaviour is through elemental analysis of obsidian from geological sources and from archaeological artefacts. In most cases obsidian from an individual eruptive event has an elemental composition that is distinct from obsidian erupted during another event, so that artefacts can be attributed to a specific source on the basis of their composition (Glascock et al., 1998, Agazi Negash et al., 2006). In this way it has been possible to identify the procurement and transport of obsidian from the source to habitation sites.

However, the geological provenance of many MSA artefacts in Ethiopia remains unknown because there is no comprehensive inventory of analyses from sources, and also because many artefacts have not been analyzed. A comprehensive program of investigating the composition of obsidian sources and archaeological obsidian at MSA sites will take many years of intensive research. This paper is but a beginning toward characterization of obsidian artefacts from MSA sites in the central part of the Ethiopian Rift. The analyses were made on artefacts that are stored in the National Museum of Ethiopia, and also on geological source obsidians collected for purposes of comparison.

\section{The archaeological sites}

The Middle Stone Age archaeological sites of Gademotta and Kulkuletti are situated in the lakes region in the central sector of the Main Ethiopian Rift Valley. They lay very close to the western edge of Lake Ziway, on the upper slopes of Gademotta ridge, a prominence that rises a few hundred meters above the surface of Lake Ziway and a few $\mathrm{km}$ from the town of the same name (Fig. 1). The region in which these sites are found is well known for paleoclimatic and paleoenvironmental studies and includes one of the best dated Pleistocene stratigraphic sequences in the world, as recently reviewed by Le Turdu et al. (1999), Benvenuti et al. (2002), and Morgan and Renne (2008), although archaeological investigations in the region are still sparse. 


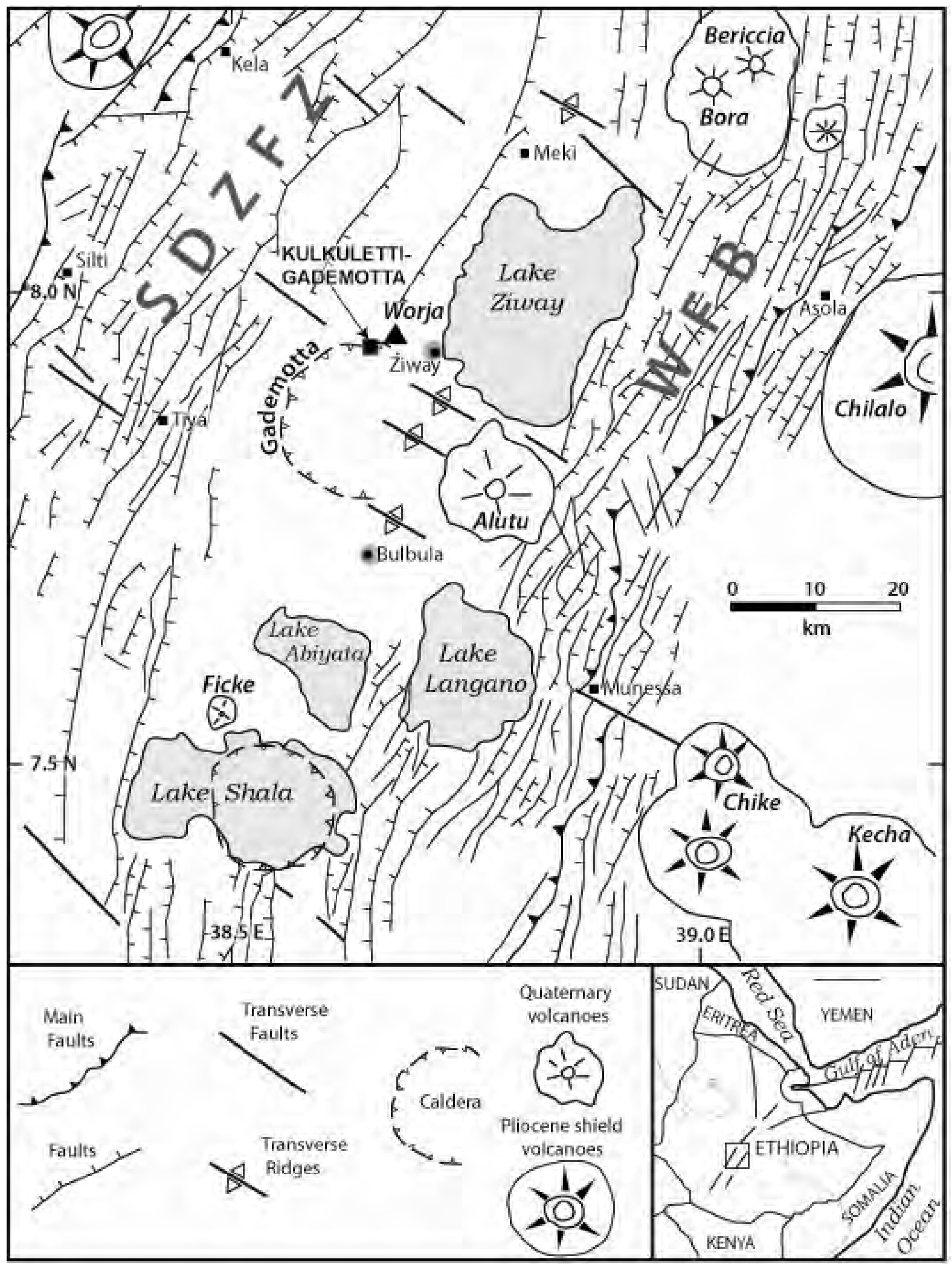

Fig. 1. Map showing the volcano-structural features of the central part of the Main Ethiopian Rift (MER) and the location of the archaeological sites and geological sources discussed in the text. WFB, Wonji Fault Belt; SDZFZ, Silti-Debre Zeit Fault Zone (modified from Benvenuti et al., 2002). Note the alignment of the Alutu and Bericcia Quaternary volcanoes along the tectonically active NNE-trending WFB within the MER. 
Excavated in the early 1970's by Wendorf and colleagues (e.g., Wendorf and Schild, 1974), the sites of Gademotta and Kulkuletti have yielded the earliest MSA artefacts in Ethiopia, and perhaps in the world. The artefacts were excavated from the Gademotta Formation, a sequence of volcanogenic stratified clastic sediments that lie unconformably on the Kulkuletti volcanics that form much of the base of the Gademotta ridge. Although the Gademotta Formation varies in thickness from $<1 \mathrm{~m}$ to $40 \mathrm{~m}$, it is $20 \mathrm{~m}$ thick in the type area (Laury and Albritton, 1975) with archaeological materials restricted to the upper $10 \mathrm{~m}$ of the section (Wendorf et al., 1994). Laury and Albritton (1975) subdivide the Gademotta Formation into two parts, a lower part (their Units 1-8) that lacks artefacts and an upper section with abundant artefacts (beginning at Unit 9). Early K/Ar dates of $235 \pm 5 \mathrm{ka}$, and $181 \pm 6 \mathrm{ka}$ on Unit 10, and $149 \pm 13$ ka on unit D (Laury and Albritton, 1975; Wendorf et al., 1994) in the upper part of the section have been supplemented by new determinations of Morgan and Renne (2008). The careful study of the latter authors reports ${ }^{40} \mathrm{Ar} /{ }^{39} \mathrm{Ar}$ ages of $280 \pm 8 \mathrm{ka}$, and $276 \pm 4 \mathrm{ka}$ for Unit 10 at the Kulkuletti and Gademotta sites, respectively, and of $183 \pm 10$ ka on unit D. Further, Morgan and Renne (2008) correlate Unit 10 between the two sites on the basis of similarity in composition of volcanic glass. These ages make the sites of Gademotta and Kulkuletti the earliest dated MSA sites in the Horn of Africa, and as old as those reported from the Kapthurin Formation in Kenya (Deino and McBrearty, 2002).

MSA artefacts from Gademotta and Kulkuletti include Levallois points and cores. Wendorf and Schild (1974) suggest that these probably represent habitation sites or base camps with obsidian workshops. There are obsidian sources close to the Gademotta and Kulkuletti sites, and it has been hitherto thought that these provided all the raw materials utilized by the prehistoric inhabitants of the sites. To test this notion, we analyzed 13 archaeological debitage samples as well as geological samples from other sources in the region that form the basis for this work. The artefacts were randomly selected from the excavated materials stored at the National Museum of Ethiopia. The analyzed source materials are artefact quality obsidian samples taken from many different parts of each source due to concern about intra-source elemental variability (Hughes, 1994, 1998; Ericson and Glascock, 2004).

\section{The potential geological sources}

As part of a project of documenting Ethiopian obsidians, we surveyed the region around the Gademotta area for potential obsidian sources. We identified three volcanic source areas with artefact quality obsidians (Worja, Alutu, and Bericcia) and one (Butajira) with porphyritic obsidians unsuitable for artefact manufacture. The latter source is, therefore, not discussed here.

The Worja source area (average location $7.9411^{\circ} \mathrm{N}, 38.6557^{\circ}$ E) forms part of the Gademotta caldera, located along the tectonically active Wonji Fault Belt (WFB) in the Main Ethiopian Rift on the Ziway-Langano-Abiata rift floor. It is adjacent to the Guraghe escarpment where there is an active western marginal graben called the 'Silti-Debre Zeit Fault Zone' (Giday WoldeGabriel et al., 1990; Fig. 1). The western rim of the Gademotta caldera forms an arcuate structure of pantellerite ridges and domes whereas younger deposits largely cover the eastern rim. In some sections of the eastern rim of the caldera, outcrops of rhyolite/pantellerite containing thin, fragmented obsidian layers are exposed, and obsidian pebbles and boulders are abundant (Fig. 2). In other places, intact steeply dipping obsidian layers intercalate with the rhyolite/pantellerite flows. This section, known as the Kulkuletti volcanics, attains a maximum thickness of $100 \mathrm{~m}$, and has yielded a K/Ar age of $1.048 \pm 0.025 \mathrm{Ma}$ (Laury and Albritton, 1975). Giday WoldeGabriel et al. (1990) report a K/Ar age of $1.3 \mathrm{Ma}$ on a rhyolite from this section, which is confirmed by some of the ages measured by Vogel et al. (2006) and substantiated by reanalysis of Vogel's data by Brown et al. (2009) and Morgan et al. (2009). Obsidian samples from the Worja locality in Gademotta are black to dark green, with flow banding, patches of oxidized material, and typical conchoidal fracture. In this area obsidian occurs as thin, highly fragmented flow layers, so abundant gravels and boulders are very common. 


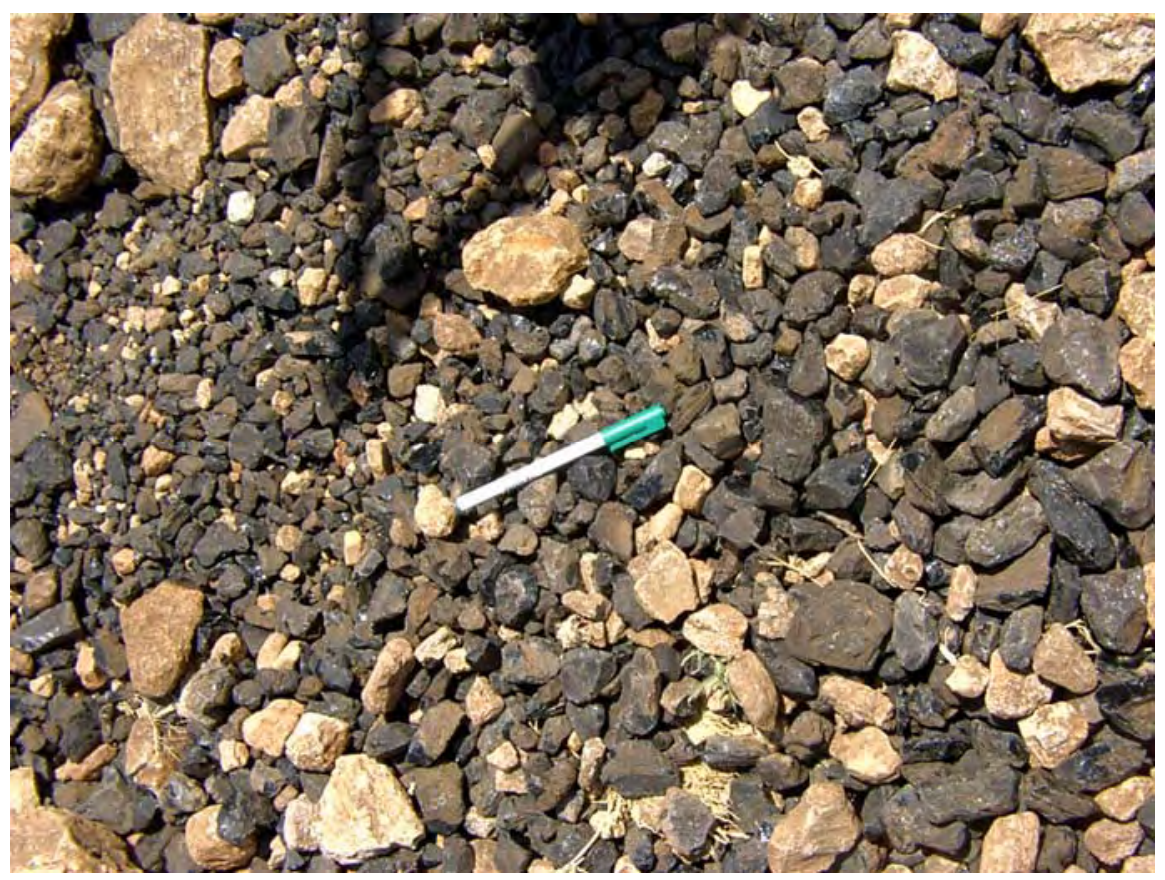

Fig. 2. Obsidian pebbles from Worja locality.

A second potential obsidian source which we sampled is Bericcia volcano $\left(8.0444^{\circ} \mathrm{N}, 39.0178^{\circ}\right.$ E), near the small town of Ogolcho. Volcanism in the Bericcia area is part of the Main Ethiopian Rift volcanic complex along the Langano-Ziway segment of the WFB and, as at Alutu (see below), is characterized by rhyolitic lava flows, domes and pyroclastic rocks including pumice, tuff, obsidian and pitchstone. Patches of obsidian/pitchstone are common within one rhyolitic flow unit in the Ogolcho-Bericcia area. The obsidian (pitchstone) is generally non-vitreous, black, and found intercalated within rhyolitic ignimbrites that are generally light grey, vesicular, and in some cases flow banded.

Like Bericcia, Alutu volcano $\left(7.7381^{\circ} \mathrm{N}\right.$, $\left.38.7914^{\circ} \mathrm{E}\right)$ lies along the Langano-Ziway segment of the WFB (Fig. 1). It has rhyolitic lava flows and domes associated with the rift floor ignimbrites. It has been dated at $1.3 \pm 0.1 \mathrm{Ma}$ on rhyolite lava and $0.04 \pm 0.01 \mathrm{Ma}$ on obsidian (Giday WoldeGabriel et al., 1990). On the slopes of Alutu volcano, exposures of a mass of obsidian up to 3 to $5 \mathrm{~m}$ thick are common (Fig. 3). On the lower slopes, obsidian flows intercalate with a rhyolitic lava flow whereas in the upper part the obsidian is interlayered with an oxidized and weathered friable unit. The obsidian is black, vitreous, and has a characteristic conchoidal fracture and flow structure, with folded flow bands.

\section{METHOD}

Samples were analyzed using two instruments: energy dispersive $\mathrm{x}$-ray fluorescence (EDXRF) for trace elements and electron microprobe for major and minor elements. Trace elements were analysed at the Archaeological XRF laboratory of the Department of Anthropology, University of California, Bereley.

We did not measure the major/minor elements for the artefacts because they were destroyed as they were irradiated for $\mathrm{Ar} / \mathrm{Ar}$ age determination (Vogel et al., 2006) and therefore only their trace element concentrations (analyzed before irradiation) are reported here. It should be noted that samples labelled GADT-1 through GADT-13 correspond to samples Kulkuletti-1 through Kulkuletti-13 of Vogel et al. (2006), and in addition, the sample labelled Worja-3 in Vogel et al. (2006) is labelled Worja-A here.

Analytical details for EDXRF obsidian characterization have been described elsewhere (Shackley, 1998; Agazi Negash and Shackley, 2006; Agazi Negash et al., 2007). Details of the method used for analysis by electron microprobe are provided in Nash (1992), and Brown et al. (2006) give standards used and analytical conditions for each element as a supplementary table. 


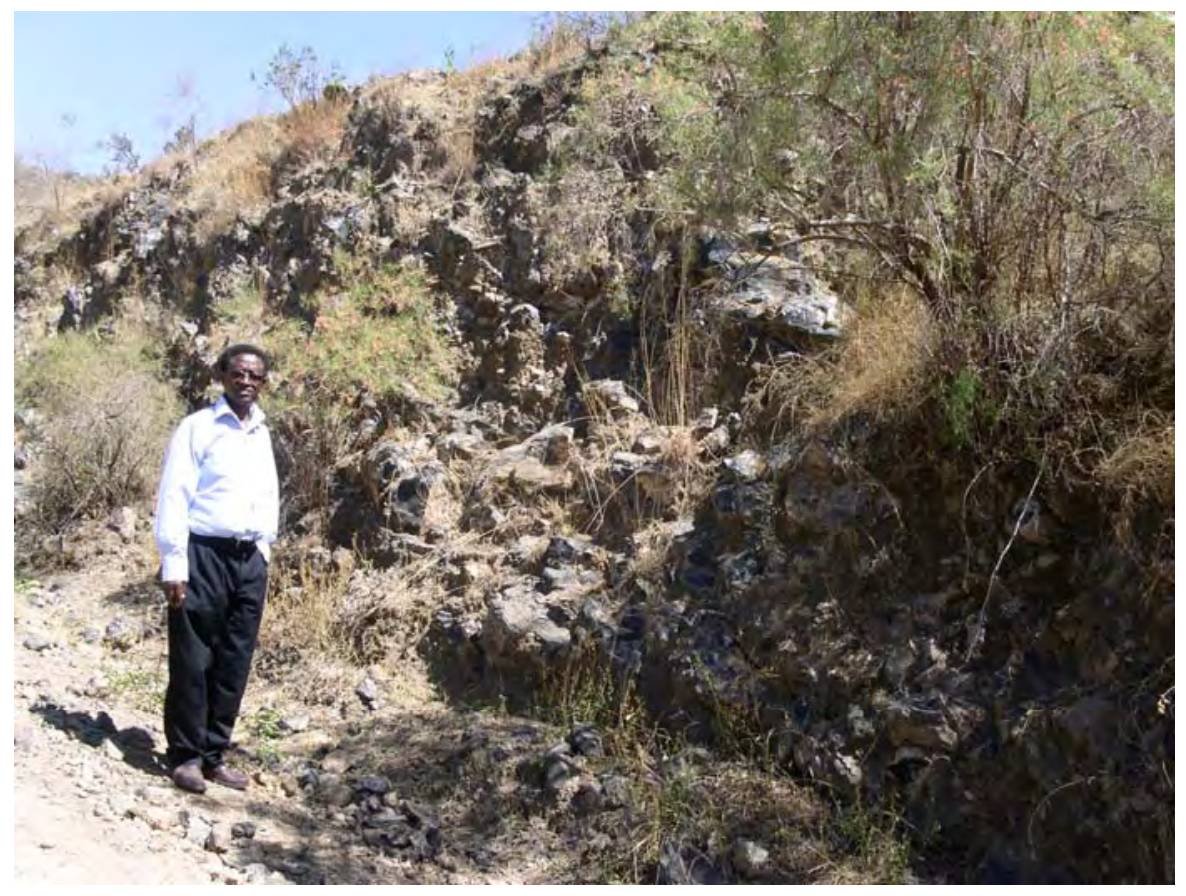

Fig. 3. Obsidian flow from Alutu volcano.

\section{RESULTS AND DISCUSSION}

Compositional results are presented in Table 1 (for major and minor elements) and Table 2 (for trace elements) and plotted in Figure 4. Simple discrimination of the sources can be made on the basis of $\mathrm{Fe}, \mathrm{Al}, \mathrm{Mn}$, and $\mathrm{Ca}$. For instance, the Worja source samples can be separated from the rest by their lower Fe content (Fig. 4). Of the three clusters, obsidian from Alutu has the highest concentration of $\mathrm{Fe}$ and $\mathrm{Mn}$ while Bericcia has a higher concentration of alumina (in excess of 11.7 wt \%, Fig.4) and also a higher Ca concentration (Table 1).

The artefacts can easily be grouped into two distinct compositional clusters on the basis of $\mathrm{Zr}$. Most of the artefacts correspond compositionally to source obsidian from Worja, located close to the archaeological sites. However, two of the artefacts (GADT-9 and -10) are compositionally distinct, with $\mathrm{Zr}$ content some $300 \mathrm{ppm}$ lower than the main group of artefacts. These come from a source that we have not yet located. In many respects these two artefacts are compositionally similar to the obsidians from Bericcia, but are distinct in their higher $\mathrm{Nb}$ content and lower Sr content (Table 2). This leaves only Alutu as a possible source for which we have compositional data.

Analyses of source samples from Alutu located some thirty $\mathrm{km}$ southeast of the sites (Fig. 1), suggest that at least two and possibly three compositional types are present on that volcano. The principal group of seven samples (Alutu F-1, F-2, F-3, F-A, S-4, S-5, and S-6) is well defined, and is most similar to the artefact compositions in trace element contents. Source samples Alutu S-1 and S-2 are clearly distinct from the main group of samples from Alutu in having higher $\mathrm{Zn}, \mathrm{Rb}, \mathrm{Y}, \mathrm{Zn}, \mathrm{Zr}, \mathrm{Nb}$ and $\mathrm{Cl}$, and also in having lower contents of $\mathrm{CaO}, \mathrm{TiO}_{2}, \mathrm{Al}_{2} \mathrm{O}_{3}$ and $\mathrm{Fe}_{2} \mathrm{O}_{3}$. Sample Alutu S-3 has trace element contents similar to the principal group, but has Fe content similar to that of Alutu S-1 and S-2; on the basis of the data available, we treat it as compositionally distinct from both.

That two artefacts are clearly not derived from obsidian from Worja, but from another source demonstrates that the people who made the tools sometimes used material from other localities, even though good material was available nearby (Merrick et al., 1994). Although contact, exchange, and even curated transport have been invoked to explain the presence of non-local raw materials at an archaeological site, such explanations require prior extensive regional archaeological evidence. The scarcity of archaeological investigations in the central part of the Ethiopian Rift precludes determining of how obsidians of Gademotta from an unknown source were procured. 


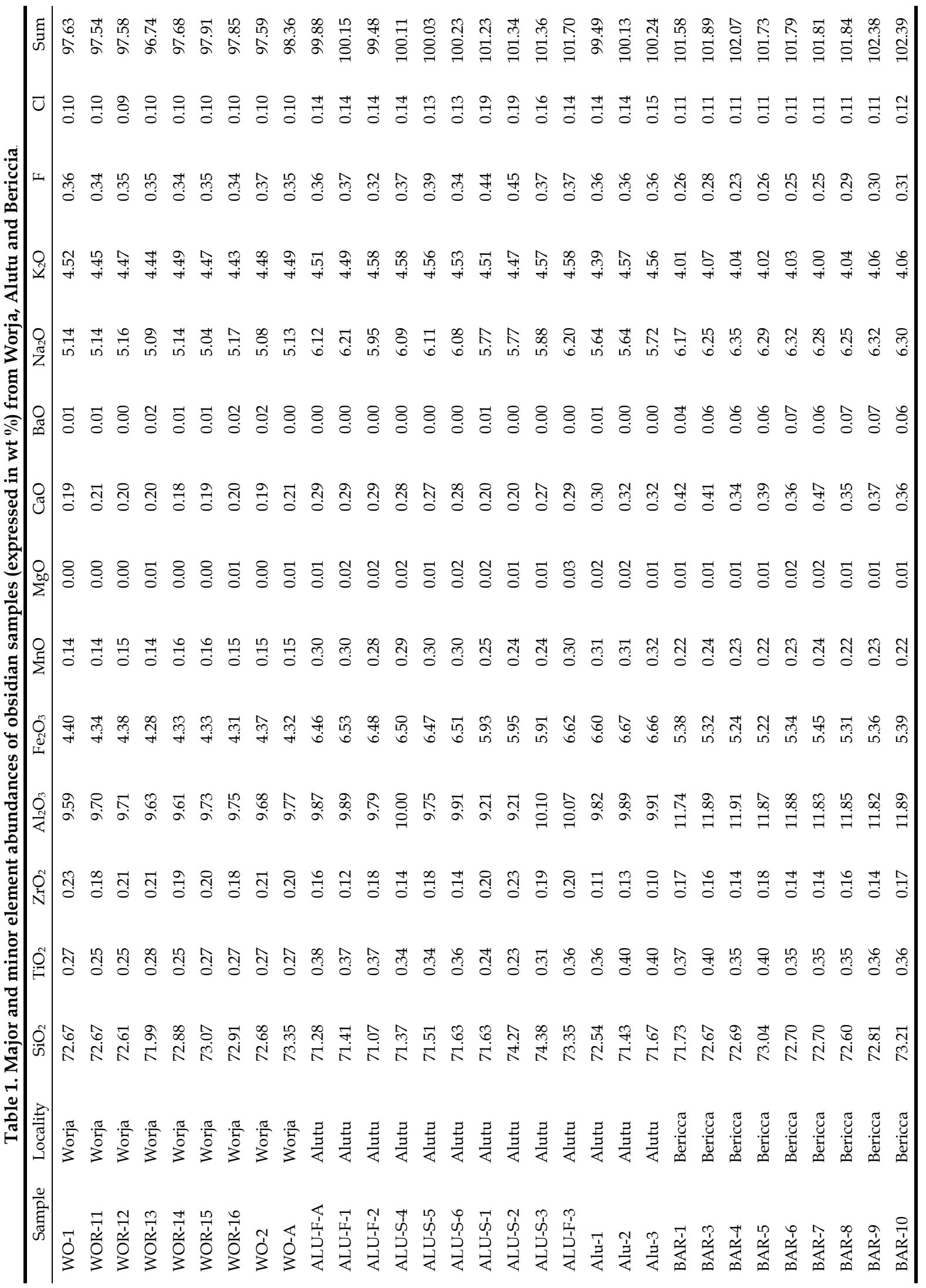


Table 2. Trace element composition (in ppm) of the Gademotta artefacts and from the sources of Worja, Alutu and Bericcia.

\begin{tabular}{|c|c|c|c|c|c|c|c|c|}
\hline Sample & Legend & $\mathrm{Zn}$ & $\mathrm{Ga}$ & $\mathrm{Rb}$ & $\mathrm{Sr}$ & $\mathrm{Y}$ & $\mathrm{Zr}$ & $\mathrm{Nb}$ \\
\hline GADT-1 & artefact & 264 & 26 & 112 & 15 & 123 & 1036 & 130 \\
\hline GADT-2 & artefact & 277 & 30 & 109 & 18 & 122 & 1048 & 140 \\
\hline GADT-3 & artefact & 262 & 27 & 104 & 16 & 127 & 1031 & 125 \\
\hline GADT-4 & artefact & 264 & 26 & 108 & 17 & 121 & 989 & 136 \\
\hline GADT-5 & artefact & 258 & 27 & 115 & 19 & 121 & 1012 & 135 \\
\hline GADT-6 & artefact & 298 & 31 & 116 & 15 & 124 & 1064 & 138 \\
\hline GADT-7 & artefact & 258 & 29 & 103 & 17 & 128 & 1013 & 139 \\
\hline GADT-8 & artefact & 275 & 26 & 109 & 17 & 128 & 1027 & 134 \\
\hline GADT-9 & artefact & 238 & 27 & 95 & 11 & 103 & 755 & 137 \\
\hline GADT-10 & artefact & 245 & 27 & 87 & 13 & 95 & 749 & 144 \\
\hline GADT-11 & artefact & 261 & 25 & 102 & 19 & 123 & 991 & 129 \\
\hline GADT-12 & artefact & 226 & 30 & 101 & 19 & 109 & 924 & 121 \\
\hline GADT-13 & artefact & 257 & 30 & 109 & 15 & 119 & 995 & 135 \\
\hline WO-1 & Worja & 269 & 34 & 104 & 14 & 116 & 1002 & 141 \\
\hline WO-2 & Worja & 264 & 28 & 115 & 17 & 117 & 989 & 123 \\
\hline WO-A & Worja & 268 & 27 & 106 & 13 & 120 & 984 & 132 \\
\hline WOR-11 & Worja & 264 & 28 & 105 & 17 & 120 & 1005 & 132 \\
\hline WOR-12 & Worja & 247 & 21 & 97 & 19 & 116 & 931 & 123 \\
\hline WOR-13 & Worja & 276 & 24 & 112 & 18 & 124 & 1017 & 124 \\
\hline WOR-14 & Worja & 255 & 34 & 109 & 16 & 127 & 981 & 130 \\
\hline WOR-15 & Worja & 295 & 28 & 104 & 19 & 130 & 1062 & 141 \\
\hline WOR-16 & Worja & 270 & 26 & 109 & 16 & 126 & 1026 & 140 \\
\hline BAR-1 & Bericcia & 211 & 27 & 95 & 19 & 89 & 708 & 109 \\
\hline BAR-3 & Bericcia & 208 & 29 & 91 & 17 & 81 & 677 & 108 \\
\hline BAR-5 & Bericcia & 233 & 27 & 94 & 21 & 92 & 722 & 127 \\
\hline BAR-7 & Bericcia & 208 & 29 & 94 & 25 & 82 & 702 & 108 \\
\hline BAR-8 & Bericcia & 231 & 32 & 97 & 20 & 87 & 714 & 116 \\
\hline BAR-10 & Bericcia & 264 & 34 & 109 & 18 & 83 & 752 & 119 \\
\hline ALU-S-1 & Alutu & 307 & 30 & 120 & 16 & 127 & 1057 & 189 \\
\hline ALU-S-2 & Alutu & 321 & 28 & 115 & 18 & 134 & 1071 & 192 \\
\hline ALU-S-3 & Alutu & 252 & 27 & 90 & 16 & 94 & 855 & 140 \\
\hline ALU-S-4 & Alutu & 242 & 27 & 93 & 19 & 93 & 792 & 142 \\
\hline ALU,S-6 & Alutu & 248 & 30 & 98 & 13 & 86 & 758 & 142 \\
\hline ALU,S-5 & Alutu & 253 & 30 & 95 & 13 & 89 & 781 & 137 \\
\hline ALU,F-A & Alutu & 253 & 33 & 88 & 20 & 96 & 774 & 147 \\
\hline ALU-F-1 & Alutu & 287 & 31 & 102 & 17 & 103 & 828 & 162 \\
\hline ALU-F-2 & Alutu & 272 & 31 & 96 & 12 & 99 & 804 & 133 \\
\hline ALU-F-3 & Alutu & 280 & 31 & 106 & 13 & 93 & 826 & 145 \\
\hline
\end{tabular}




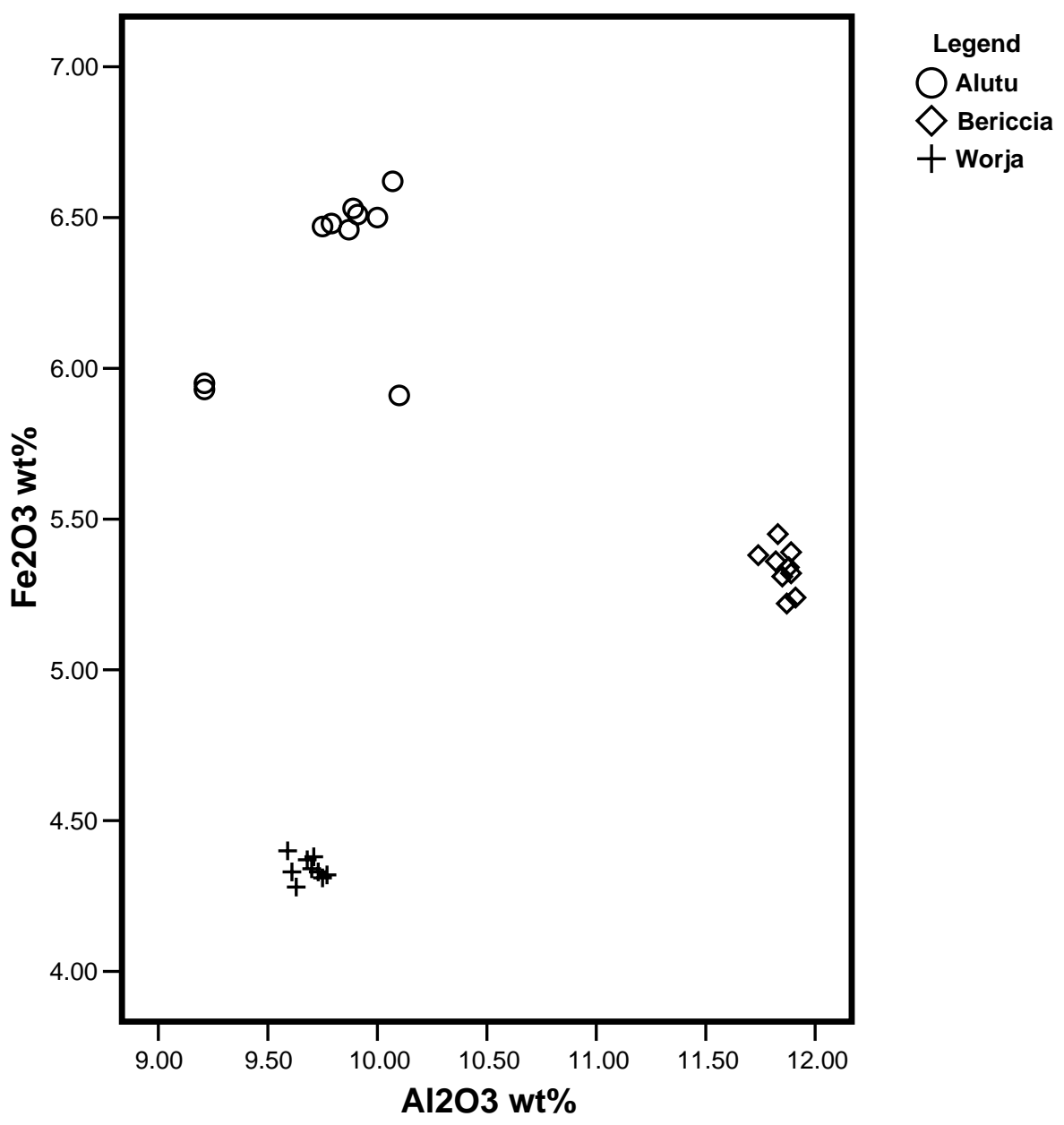

Fig. 4. $\mathrm{Fe}_{2} \mathrm{O}_{3}{ }^{\mathrm{T}}-\mathrm{Al}_{2} \mathrm{O}_{3}$ binary diagram discriminating obsidians from different sources (Alutu, Bericcia, and Worja). Note at least three clusters for the three different sources.

\section{CONCLUSION}

There is good evidence that most of the artefacts at the Gademotta sites were obtained from local raw materials, but some artefacts were made of material from sources that we have not located locally. This strongly implies that there was movement of raw material and/or artefacts from another source. This has also been demonstrated in other investigations in East Africa that showed some artefacts were being procured from nonlocal sources despite the presence of ample, good quality local obsidians (Merrick and Brown, 1984; Merrick et al., 1994). Current archaeological evidence does not allow any inference to be made as to whether raw material was procured directly, or whether there was some sort of interaction/exchange with other places, considered as a key aspect of the advent of modern human behaviour.

\section{ACKNOWLEDGEMENTS}

The research work presented here was graciously funded by the L.S.B. Leakey Foundation, the WennerGren foundation, and Paleontological Scientific Trust (PAST). A.N. would like to thank Tim White for funding through the Laboratory for Human Evolutionary Studies, University of California, Berkeley, when the trace elements of both the artefacts and sources were determined at the Archaeological XRF laboratory, Department of Anthropology. Thanks are also due to its director, M.S. Shackley. National Science Foundation BCS06-21543 provided support for some analyses. Thanks also go to the Authority for Research and Conservation of Cultural Heritage (ARCCH), the Ethiopian government agency that oversees archaeo- 
logical/paleontological investigations in the country, for permits.

\section{REFERENCES}

1. Agazi Negash, Mulugeta Alene, Brown, F., Nash, B. and Shackely, M.S. (2007). Geochemical Provenance of the Terminal Pleistocene/Early Holocene Obsidian Artefacts from the Site of Beseka, Central Ethiopia. Journal of Archaeological Science 34:1205-1210.

2. Agazi Negash and Shackley, M.S. (2006). Geochemical provenance of obsidian artefacts from the MSA site of Porc Epic, Ethiopia. Archaeometry 48:1-12.

3. Agazi Negash, Shackley, M.S. and Mulugeta Alene (2006). Source Provenance of Obsidian Artefacts from the Early Stone Age (ESA) site of Melka Konture. Journal of Archaeological Science 33:1647-1650.

4. Benvenuti, M., Carnicelli, S., Belluomini, G., Dainelli, N., DiGrazia, S., Ferrari, G.A., Lasio, C., Sagri, M., Ventra, D., Balemwal Atnafu and Seifu Kebede (2002). The Ziway-Shala lake basin (main Ethiopian rift, Ethiopia): a revision of basin evolution with special reference to the Late Quaternary. Journal of African Earth Sciences 35:247-269.

5. Brown, F.H., Bereket Haileab and McDougall, I. (2006). Sequence of tuffs between the KBS Tuff and the Chari Tuff in the Turkana Basin, Kenya and Ethiopia. Journal of the Geological Society 163:185-204.

6. Brown, F.H., Reid, C. and Agazi Negash (2009). Possible isotopic fractionation of argon in source obsidians and archaeological artefacts from Kulkuletti, Ethiopia. Journal of Archaeological Science 36:2119-2124.

7. Deino, A.L. and McBrearty, S. (2002). ${ }^{40} \mathrm{Ar} /{ }^{39} \mathrm{Ar}$ dating of the Kapthurin Formation, Baringo, Kenya. Journal of Human Evolution 42:185-210.

8. Ericson, J.E. and Glascock, M.D. (2004). Sub-source characterization: obsidian utilization of subsources of the Coso Volcanic Field, Coso Junction, California, USA. Geoarchaeology 19:779-806.

9. Giday WoldeGabriel, Aronson, J.A. and Walter, R.C. (1990). Geology, geochronology, and rift basin development in the central sector of the Main Ethiopian Rift. Geological Society of America Bulletin 102:439-358.

10. Glascock, M.D., Braswell, G.E. and Cobean, R.H. (1998). A systematic approach to obsidian source characterization. In: Archaeological Obsidian Studies: Method and Theory, pp.15-66, (Shackley, M.S., ed.). Plenum Publishing Company, New York.
11. Hughes, R.E. (1994). Intrasource separation of artefact-quality obsidians from the Casa Diablo Area, California. Journal of Archaeological Science 21:263-271.

12. Hughes, R.E. (1998). On reliability, validity, and scale in obsidian sourcing research. In: Unit Issues in Archaeology: Measuring Time, Space, and Material, pp. 103-114, (Ramenofsky, A.F. and Steffen, A., eds). University of Utah Press, Salt Lake City.

13. Laury, R.L. and Albritton, C.C. (1975). Geology of Middle Stone Age archaeological sites in the main Ethiopian Rift Valley. Geological Society of America Bulletin 86:999-1011.

14. Le Turdu , C., Tierceliln, J-J., Gilbert, E., Travi, Y., Lezzar, K-E., Richert, J-P., Massault, M., Gasse, F., Bonnefille, R., Decobert, M., Gensous, B., Jeudy, V., Endale Tamirat., Mohammed Umer., Martens, K., Balemwal Atnafu, Tesfaye Chernet, Williamson, D. and Taieb, M. (1999). The Ziway-Shala lake basin system, Main Ethiopian Rift: Influence of volcanism, tectonics, and climatic forcing on basin formation and sedimentation. Palaeogeography, Palaeoclimatology, Palaeoecology 150:135-177.

15. McBrearty, S. and Brooks, A. (2000). The revolution that wasn't: a new interpretation of the origin of modern human behaviour. Journal of Human Evolution 39:453-563.

16. Merrick, H.V. and Brown, F.H. (1984). Obsidian sources and patterns of source utilization in Kenya and northern Tanzania: some initial findings. African Archaeological Review 2:129152.

17. Merrick, H.V., Brown, F.H. and Nash, W.P. (1994). Use and movement of obsidian in the Early and Middle Stone Ages of Kenya and northern Tanzania. In: Society, Culture, and Technology in Africa, pp. 29-44, (Childs, S.T., ed). MASCA 11.

18. Morgan, L. and Renne, P. (2008). Diachronous dawn of Africa's Middle Stone Age: New ${ }^{40} \mathrm{Ar} /{ }^{39} \mathrm{Ar}$ ages from the Ethiopian Rift. Geology 36:967-970.

19. Morgan, L.E., Renne, P.R., Taylor, R.E. and Giday WoldeGabriel (2009) Archaeological age constraints from extrusion ages of obsidian: Examples from the Middle Awash, Ethiopia. Quaternary Geochronology 4:193-203.

20. Nash, W.P. (1992). Analysis of oxygen with the electron microprobe: Applications to hydrated glass and minerals. American Mineralogist 77:453-457.

21. Shackley, M.S. (1998). Gamma rays, X-rays, and stone tools: some recent advances in archaeological geochemistry. Journal of Archaeological Science 25:259-270. 
22. Vogel, N., Nomade, S., Agazi Negash and Renne, P. (2006). Forensic ${ }^{40} \mathrm{Ar} /{ }^{39} \mathrm{Ar}$ dating: a provenance study of Middle Stone Age obsidian artefacts from Ethiopia. Journal of Archaeological Science 33:1739-1765.

23. Wendorf, F. and Schild, R. (1974). A Middle Stone Age Sequence from the Central Rift Valle, Ethiopia. Polish Academy of Sciences, Warsaw.
24. Wendorf, F., Close, A.E. and Schild, R. (1994). Africa in the period of Homo sapiens neanderthalensis and contemporaries. In: History of Humanity, Vol. 1: Prehistory and the Beginnings of Civilization, pp. 117-135, (de Laet, S., Dani, A. and Nunoo, B., eds) Routledge and UNESCO: New York. 